\title{
THE INDIAN HIMALAYA`S UNIQUE ATTRIBUTES: HEMKUND SAHIB AND THE VALLEY OF FLOWERS
}

\author{
Shiv Kumar GUPTA 1 , Radu NEGRU ${ }^{2}$, Mihai VODA ${ }^{2}$
}

DOI: 10.21163/GT_2018.132.05

\begin{abstract}
:
The Indian Himalayan ranges with towering snowclad peaks and deep valley river rapids present a variety of common geographical features. The high mountain environments gained social values due to the influence of the human ancient cultures. The spiritual dimension of the geographical space generated its unique attributes. This research investigates some of the most intriguing mountain locus which are defined by a cumulus of special characteristics. We identified the uniqueness generating factors using the geomedia techniques. Furthermore, this study analyses the interconnection between Hemkund Sahib and Valley of Flowers Geosystems` different components. Our research findings present the functionality of two selected dynamic Himalayan geosystems in a significant equilibrium state. This result of this paper will contribute to the preservation of Hemkund Sahib and Valley of Flowers' unique features and future promotion using the new technical Geography advances.
\end{abstract}

Key-words: Himalayas, attributes, Hemkund Sahib, geo-apps, Valley of Flowers.

\section{INTRODUCTION}

The Indian Himalaya's unique attributes based on the Geosystems grounded theory approach, using the modern technical Geography tools in an attempt to provide innovative solutions for the increasingly visited mountain sites (Voda et al, 2014). This paper has analyzed geographical spaces that are characterized by special features, generated from the interaction between the environmental components and the central element of any geosystem: the human being.

The Valley of Flowers National Park lies in the main valleys of Alaknanda and Dhauli Ganga in the Garhwal Himalayas in Chamoli district of Uttarakhand State in India. Valley of flowers also known in Hindu mythology as Nandan Kanan meaning "Garden of Indra in Paradise" has been declared as a National Park (VOFNP)as per Notification No. 4278/XIV 3-66-80 with effect from September 6, 1982, the intention having been declared under Notification No. 5795/XIV-3-66-80 of 1 January 1981. After notification of the Park, grazing and camping are not permitted.

Given the status of World Heritage site in 2005 VOFNP is one amongst the nine zones or part of the Nanda Devi Biosphere Reserve (NDBR) which is spread across an area of $5860.69 \mathrm{sq} \mathrm{km}$. Located between the Latitude $30^{\circ} 41^{\prime}-30^{\circ} 48^{\prime} \mathrm{N}$ and Longitude $79^{\circ} 33^{\prime}$ $79^{\circ} 46^{\prime} \mathrm{E}$ VONP covers an area of $87.5 \mathrm{sq} . \mathrm{km}$. The altitude of the valley ranges from 3200 $\mathrm{m}$ to $6700 \mathrm{~m}$.

River Pushpawati flows through this valley which has its source in the Tipra Glacier which extends up to Ghori Parbat peak. It is a flat valley $5 \mathrm{~km}$ long and $2 \mathrm{~km}$ wide. The

\footnotetext{
${ }^{1}$ H.N.B. Garhwal University, Centre for Mountain Tourism and Hospitalities Studies, SrinagarGarhwal, India, sk_gupta21@Yahoo.com;

${ }^{2}$ Dimitrie Cantemir University, 540546 Targu Mures, Romania, negrurg@yahoo.com, mihaivoda@cantemir.ro.
} 
main valley portion of the Park runs in the east west direction along the banks of river Pushpawati (Gupta, 2002).

The park is surrounded by Gauri Parbat $(6590 \mathrm{~m})$ and Rataban $(6126 \mathrm{~m})$ in the east, Kuntkhal $(4430 \mathrm{~m})$ in the west, Saptsring, in the south and Nilgiri Mountain $(6479 \mathrm{~m})$ in the north. The credit for the discovery of the Valley of Flowers generally goes to the British mountaineer Frank S. Smythe and R.L. Holds Worth who accidentally reached the valley after a successful expedition of Mount Kamet in 1931. Fascinated by its beauty and grandeur Frank S. Smythe revisited this area in 1937 and published book "The Valley of Flowers" (Smythe, 1938) which made it world famous.

The valley offers a rich plethora of unique floral wealth out of which 31 rare and endangered plant species including 11 species listed in the Red Data Book (RDB) of the Indian plants recorded within the Valley of Flowers National Park. The surrounding areas also have some beautiful Himalayan grassland and other valleys which bears many exquisite Himalayan flowers like the Himalayan lotus.

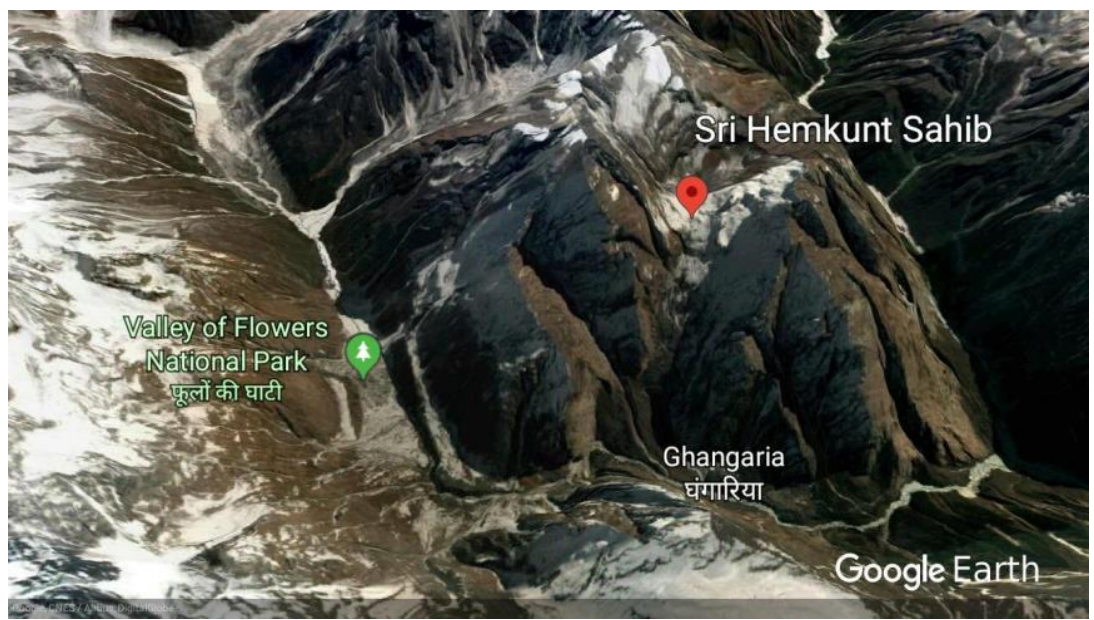

Fig. 1. Valley of Flowers and Hemkund Sahib in Google Earth geo-app (Google Earth, 2018).

Near the Valley of Flowers is the sacred place of Sikhs the Hemkund Sahib (Fig.1). It is situated at an altitude of $4329 \mathrm{~m}$, and sacred to both Sikhs and Hindus. Hemkund Shrines are one of the highest temples in India (Fonia, 1998; Kuniyal et al, 1998).

The Sikhs revere this place because their tenth Guru described its location in his holy writings, in the Dasam Sahib (the books of the Tenth Guru). Considered the Geosystem`s unique cultural attribute, Hemkund Sahib location was discovered in 1934 by Sant Sohan Singh in remembrance and prayer to see the place where their tenth guru, Guru Govind Singh meditated and realized his oneness with God along the banks of Lokpal Lake. A small Gurdwara was developed in 1935-36 (including enlarging the ancient Hindu "Lokpal" temple) and later in 1968 the construction for the present Gurdwara began which got completed in 1993. For the Hindu the lake known as Lokpal constitute the unique attribute of this geographical location from the Himalayas. Here, Lakshman, the younger brother of Lord Rama, had meditated. A small temple is dedicated to Lakshman and it stands next to the Gurudwara. Lakshman / Hem Ganga stream originates from the Lokpal Lake, which later meets river Pushpawati near Ghangharia and further flows as Bhyundar Ganga to join the river Alaknanda at Govindghat (Kaur, 1985). 
The Sikh pilgrims have been the biggest draw for tourism in this area. Every year near about 400000 pilgrims visit Hemkund and Laxman temple before 2013 but only few thousands visits the valley. Tourism plays a very important role in the sustainable development of the area as about $95 \%$ of the indigenous population depends on it. The main influx of tourists consists of Sikhs.

There is no significant difference between the common functional attributes of the Valley of Flowers and Hemkund Sahib Geosystems. Climate is moist temperate and alpine type, with short cool summers and long severe winters influenced by southwest monsoon in the summer, and western disturbances in winter. During the snow period ( 7 months early October to late April) the vegetation survives under snow with the help of tubers and rhizomes.

\section{STUDY AREA ACCESSIBILITY}

The nearest airport is Jolly Grant, which is $306 \mathrm{~km}$ away from the research area. The nearest broad-gauge railhead is Rishikesh (about $271 \mathrm{~km}$ ), while Haridwar railhead is at a distance of about $295 \mathrm{~km}$ by road from Govindghat which is about 25 kilometres before Badrinath. It is located on Rishikesh --Srinagar - Joshimath- - Govindyhat-Badrinath route. The Valley of Flowers is a trek of about $13 \mathrm{~km}$ from Pulna village which is $3 \mathrm{~km}$ from Govindghat. Govindghat is the base of the route to the Ghangharia base settlement $(14 \mathrm{~km}$ from Govindghat) and from Ghangharia subsequently one trail goes towards Valley of Flowers $(3-4 \mathrm{~km})$ and another steep trail to Hemkund Sahib $(6 \mathrm{~km})$. Four-wheel drive services are available to drop tourists from Govindghat to Pulna. Pony and palanquins are available on fixed prices by Eco Development Committee (EDC) for Ghagharia /Hemkund Sahib from Pulna. Helicopter service is also available from Govindghat to Ghangharia. The trek route for Valley of Flowers is relatively easy compared to trek stretches like from Bhyundar to Ghangharia, or that for Hemkund Sahib, which are much steeper.

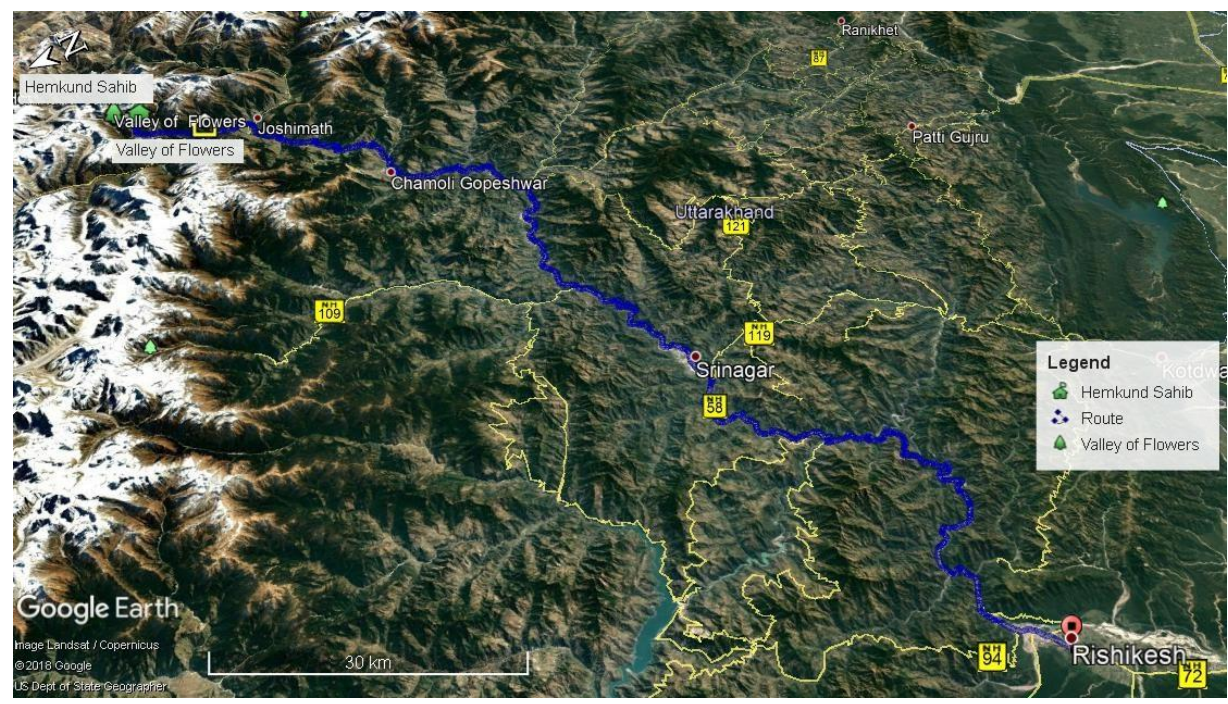

Fig. 2. The access route from Rishikesh to Valley of Flowers and Hemkund Sahib

(Google Earth, 2018). 
This trek route from Govindghat is maintained by the PWD. The Eco Development committees of Ghangharia and Govindghat are looking after the cleaning of the trek route (Gupta, 2010).

There is no settlement within the National Park (Fig. 2). Four settlements exist between the Park fringe and the motor road such as the tourist settlement of Ghangharia, villages Bhyundar, Pulna and the tourist settlement of Govindghat. The local population is about 80 families/households (about 375 persons) in Pulna, the winter settlement. Except the school going children and few elderly people, these villagers migrate to Bhyundar and Ghangharia, the summer settlements from May to early October. While women stay back at Bhyundar with small children, the men folk move further $3.75 \mathrm{~km}$ to Ghangharia, which is the central place/base in upper valley for tourist activities for 4 months from June September every year.

Small commercial establishments have been registered and regularized by a local NGO body known as Eco-Development Committee (EDC), Bhyundar under the aegis of the Department of Forest. Around 60 shops from Govindghat to Ghangharia and 15 shops from Ghangharia to Hemkund Sahib, while at Ghangharia itself some 40 private establishments of lodges/restaurants/photo studios/souvenir shops, etc. are registered. These establishments erected on Private/Nap land are called "Chak" and those on Forestland are called "Chatti" and these are either run by the villagers themselves or given on rent.

\section{METHODOLOGY}

This paper research based on the Geosystem grounded theory, has focused on the technical geography advances role in the unique attributes' identification and assessment from the Indian Himalayas. Being the most famous and intriguing, the Valley of Flowers and Hemkund Sahib Geosystems, situated in the Himalaya Mountains near the China border, has been selected for this study.

Data was gathered from different geomedia sources, non-structured interviews and field observations were carried on site in between May-June 2013 and September 2018. The collected data were analyzed using geomedia techniques that imply geo-coding procedures and theoretical sampling for the Geosystem`s carrying capacity assessment (Haidu, 2016; Voda et al, 2017).

Our theory consistency derives from the dynamic balance of the Hemkund Sahib and Valley of Flowers Geosystems, which are continuously developing in a self-sustainable way. There is a powerful connection between the environmental components and the human factors that generates the geosystems` functionality.

The theoretical elaboration is based on the reproducibility capacity of our defined geographical spaces. Their systemic characteristics and elements properties, inductively derived from gathered geo-data were identified and judged with respect to a number of evaluative criteria such as consistency, integration and predictiveness.

The Geosystem grounded theory explanatory power facilitates its application in different world`s regions as long as the defined geographical spaces fit to data. Constructed as a problem orientated endeavor, our geosystemic theory was created from solid data patterns, produced through the elaboration of Hemkund Sahib and Valley of Flowers plausible models.

Our research problems have been structured in accordance to the scientific inquiry task focused on the protection, conservation and self-sustainable development of identified 
geosystems. Once identified, the problems were selected for consideration, developed and modified.

Our geomedia techniques has also used Geosearch and Geocoding services from ArcGIS World to validate locations coordinates and Pic2Map geo-application to analyze EXIF data embedded in the photos taken on site with Xiaomi Redmi 3S and MI A2 smartphones (Ernawati et al, 2018).

\section{RESULTS AND DISCUSSIONS}

Domestic tourists form a major portion of the total tourists visiting the Himalayas. A key factor for this high domestic tourist inflow in the area is the presence of holy pilgrimages like Badrinath, and Hemkund Sahib. The shrines remain closed for six months during winters. Badrinath, by virtue of being one of the four Hindu sacred places (Dhams) of the country had been and continue to be the biggest pilgrim puller evidently, witnessing 10755883 tourist arrivals (including foreigners) in 2008 and 941092 arrivals in 2012. However, a significant decrease has been noticed in the tourist arrival at both these shrines during year 2009 over the previous year (Kandari and Gusain, 2013). The reason for this downfall can be attributed to severe road blockage due to early monsoon. The Himalayan weather problems caused by torrential rain, cloud bursts and flash floods during mid-June 2013 in this region of Uttarakhand had resulted in the severe damage to tourism infrastructure and badly affected the tourism industry and tourist traffic for the year 2013,2014 and 2015 (Gupta \& Vijay, 2013).

The pilgrim/tourist traffic is witnessing erratic growth in the Hemkund Sahib and Valley of Flower areas. Fig.3 illustrates the pilgrim/tourist traffic trends at these two places from 2005-2017. It would also be pertinent to mention here that barring Valley of Flowers, Hemkund Sahib is important from the religious/pilgrimage perspective.
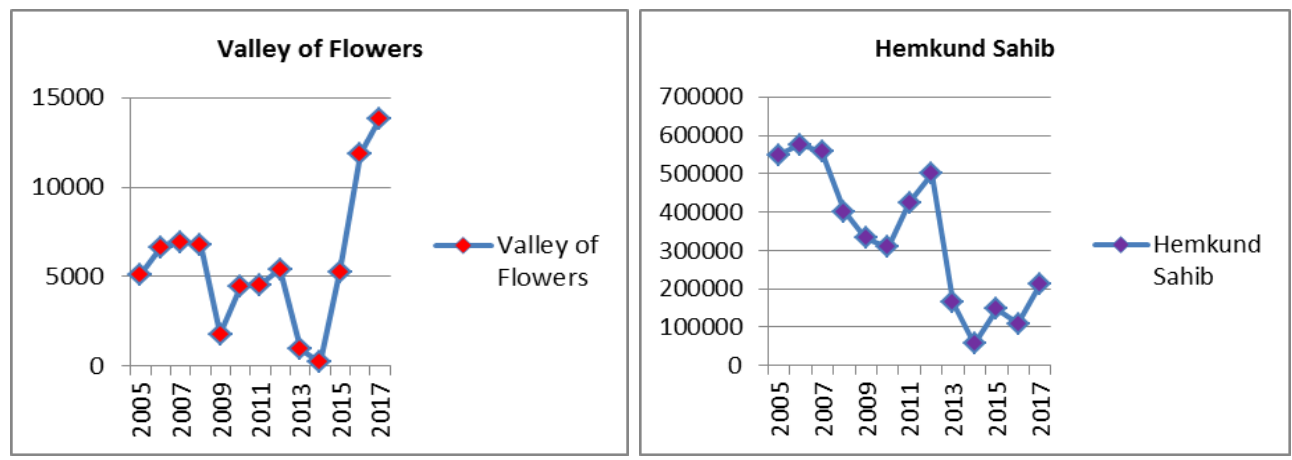

Fig. 3. The dynamic of tourist arrivals in the Valley of Flowers (left) and Hemkund Sahib (right), strongly influenced by climatic factors during 2009, 2010, 2013, 2014, 2015 and 2016.

According to Kuniyal et al (1998) the Himalayas were affected by the influence of pilgrims and the lack of infrastructural services. They proposed the sustainable reuse and recycling of the tourist garbage instead of the openly dumping of the solid waste. After 20 years the problem is solved, as we observed during our expedition in September 2018. 
EDC collects non-biodegradable waste into sacks and dump it at Govindghat from where it is sent either for recycling or for disposal.

Pulna (about $3 \mathrm{~km}$ from Govindghat) and Bhyundar (about $9 \mathrm{~km}$ from Govindghat) are the only villages, which can offer shelter (by local residents sharing their dwelling units) in an emergency of trek path getting blocked on the way to Ghangharia. Camping in tents is provided with the permission of District Forest Office (DFO), Joshimath through EDC assistance, on Forest land of the non-core zone area. From Pulna normally the trek starts in the morning during onward journey to Ghangharia/Hemkund Sahib and the return treks end at Govindghat in the evening. Gurudwara at Govindghat can accommodate up to 6000 persons comfortably and the one at Ghangharia can accommodate up to 12000 visitors in the rush season (June-July). All the visitors have to sleep on floors for which enough mattresses and blankets are available, even to meet the needs of rush season.

Sikh Gurudwaras, managed by the trust that oversees the operation of the pilgrimage to Hemkund Sahib, offer food and lodging at Rishikesh, Srinagar, and Joshimath enroute to Valley of Flowers-Hemkund Region. Govindghat has one Gurudwara, few private lodges and forest rest house for night stay. Ghangharia is the base settlement offering accommodation facilities to the tourists for night halt either for onward travel to Valley of flowers and Hemkund Sahib or return travel to Govindghat (Fig.4).

Govind Dham Gurudwara is the largest accommodation at Ghangharia. Due to its high accommodation capacity, apart from free food arrangements (Langar), majority of the visitors who are mainly on pilgrimage to Hemkund Sahib avail the Gurudwara facility. Thus, the economic flow in favor of the local communities is highly affected. The government provided accommodation like GMVN Tourist Rest House (TRH) and Forest Rest House (FRH) charge relatively high and fixed tariffs. There are around 20 private guest houses/lodges providing relatively cheaper accommodation due to fierce competition to get high occupancy. Though the accommodation in rest houses/lodges has attached bathrooms/toilets with piped water supply, hot water that is must at these cold temperatures is unavailable through piped means. But water separately heated on large kerosene/gas stoves are provided by these establishments at a reasonable cost.

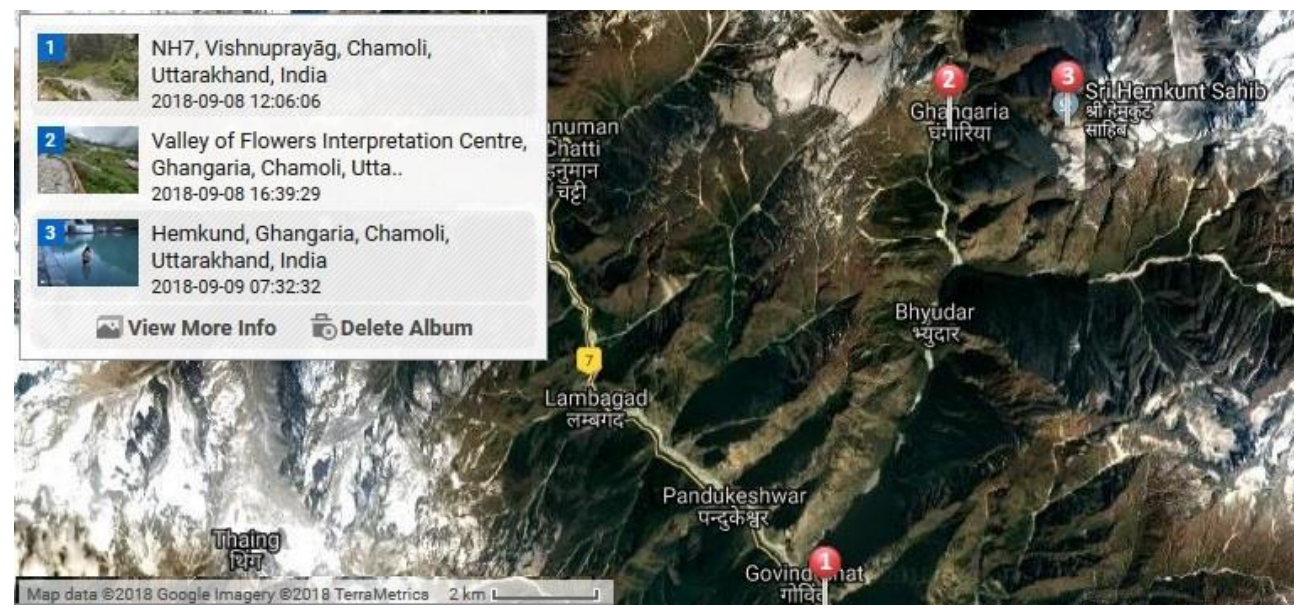

Fig. 4. The Valley of Flowers and Hemkund Sahib route from Govind Gath to Ghangharia (Pic2Map, 2018). 
At Valley of Flowers, being declared the National Park night stay is not permitted. Similarly, at Hemkund Sahib Accommodation facilities are only for Gurudwara Staff and Lokpal staff in the Gurudwara and small Dharamshala respectively and they do not encourage general stay for those who are not acclimatized to stay at such heights due to conditions of severe cold and relatively low level of oxygen. Hence, visitors need to return back and stay at nights in Govind Dham Gurudwara or other accommodation at Ghangharia (Fig.4).

Facilities for the Holy Bath (Ishnan) were observed at Hemkund Sarovar. The Sarovar with considerable cold water can generate real problems for the bold tourists who enter in the lake. There are no lifeguards on site. However, the Gurudwara staff (many of them young volunteers/sevadars) were expected to take care of pilgrim requirements and the first aid center at Hemkund Sahib with a doctor provides emergency services and necessary medicines.

Down in the valley, the Govindghat Gurudwara has dispensary and ambulances. In Govind Dham Gurudwara there is a 24 hours facility dispensary room, with one doctor and two beds for nursing the patients. Also, a small government dispensary with one doctor exists near the Govind Dham Gurudwara.

Numerous small teashops, snack bars, and temporary sheds have come up between Govindghat, Pulna, Bhyundar, Ghangharia, and Hemkund Sahib to cater to the needs of tourists during summer. Food is also available at many basic restaurants at Govindghat and Ghangharia, while the Gurudwaras at Govindghat and Ghangharia offer free food at the Langar facility. Similarly, at Hemkund Sahib free hot khichri \& tea and prasad is served to all the visitors. For quenching thirst with potable drinking water, one has to mainly depend on the packaged mineral water or soft drinks (mostly in plastic bottles, with exception of tetra packaging for thicker fluids like fruit drinks/juices).

Moreover, we observed that the overall spatial development and growth of Ghangharia has already happened in a haphazard manner, while structures have poor architectural aesthetics/construction quality with no proper water supply or solid waste disposal system in place. Currently, EDC collects eco-fee from so called hotels, lodges and restaurants, Chatti's and Chak Stalls for the four-month tourist season for environmental management along the trek path. Sewage is mostly disposed through individual septic tanks and soaks pits. Other effluents from kitchen/utensil wash flows down through open drains along the slopes at Govindghat, Pulna/ Bhyundar, Ghangharia and Hemkund Sahib. EDC has installed urinal toilets made up of pre-fabricated board body fixed on thin MS angle frames. No proper water supply is available.

Some of the EDC members from the local villages are trained guides in nature interpretation services and hence apart from their businesses they can earn additionally through guiding. From Govindghat, the taxi services are available up to Pulna village from where trek begins. Donkeys, mules (Fig.5), porters, and palkies-litter vehicles (Fig.6) can are hired mainly from Pulna or Ghangharia.

The pilgrims and tourists can rent mules and donkeys on fixed rate during peak season by the EDC by issuing of proper receipt by clearly showing the registration number of the Mule and Donkey-Kandi wala for Ghangharia, and Ghangharia to Valley of Flowers, Ghangharia- Hemkund or Pulna-Hemkund and back. The mule and donkey service constitute one of the local Geosystem`s special characteristics rarely met in other parts of the world. 

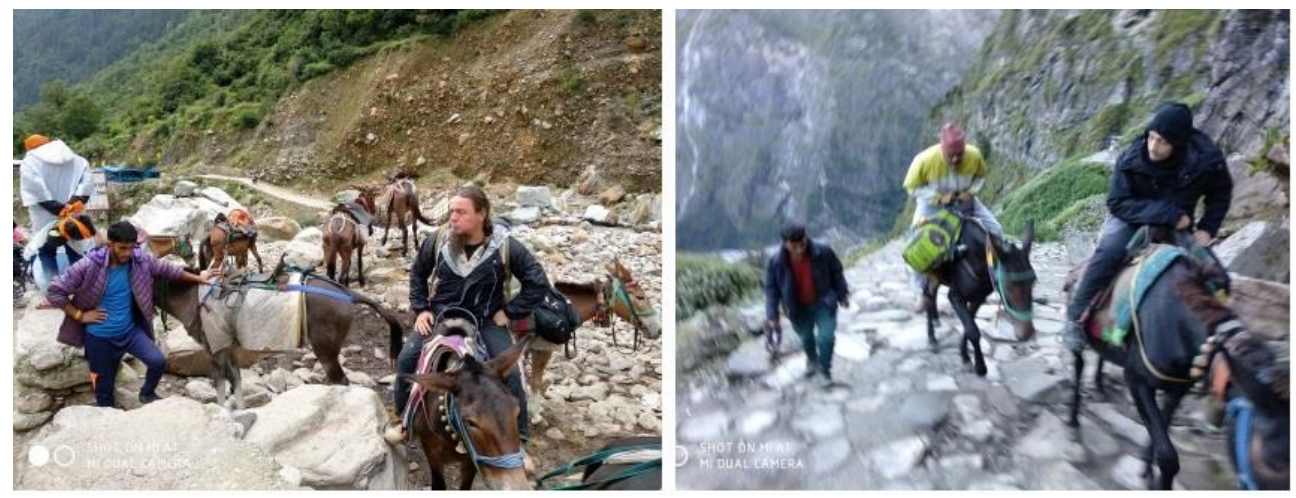

Fig. 5. The mules and donkeys from the route to Ghangharia (authors expedition`s photos).

About 800-1000 mules operate on this trek path in peak season (about 500-600 at Pulna and 300-400 are available from Ghangharia). The quadrupeds are well trained and always supervised by local guides who permanently communicate between them.

Telecommunication service is available at Ghangharia connected to a Satellite Telephone Exchange of Department of Telecommunications. Our observations pointed out that such facilities are not good en route the trek path or at Bhyundar or Pulna. There are no good telecommunications facilities at Hemkund Sahib. However, the in case of emergency wireless facility can be availed from forest officials.

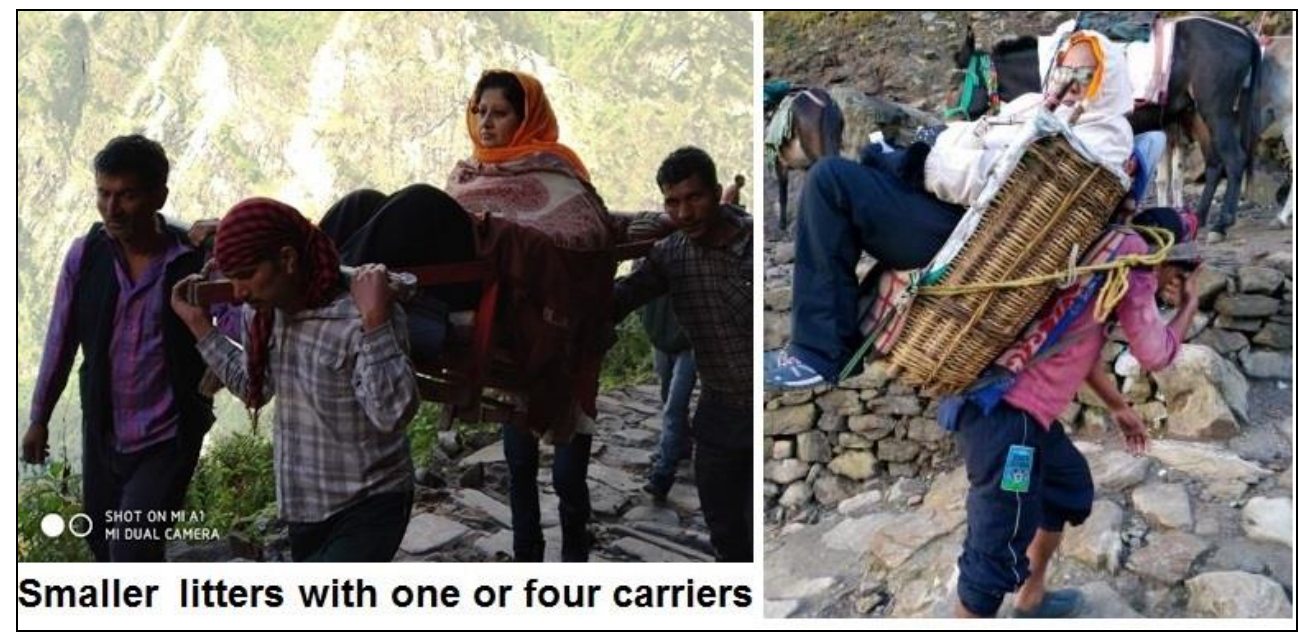

Fig. 6. The open portable litters between Ghangharia and Hemkund Sahib (authors expedition`s photos).

The pilgrimage phenomena to Hemkund Sahib generated another unique characteristic of the local Geosystems: the smaller litters in the form of open chairs, carried by one or four carriers (Fig. 6). During our exploratory research on the mountain trails we tried to understand what is driving this type of activity, undertaken by the local communities' men. However, the experience offered is unique and intriguing for any western tourist. 
Security infrastructure is supposed to be offered by the Police posts that exist at Govindghat and Ghangharia, but they do not have jurisdiction in Valley of Flowers and Hemkund Sahib area (which basically falls under the jurisdiction of Patwari, Department of Revenue based at Pandukeshwar). Any accident happening in Valley of Flowers -Hemkund region is to be attended/ recorded by the Patwari and the Police station at Govindghat is only informed for any assistance, if required.

The Valley of Flowers nature information center at Ghangharia is available in the Forest Rest House complex. At this nature interpretation center, regular (30 minute) slide shows on Valley of Flowers and wild life are held in the evening hours (from 6:00 pm 7:30 pm) throughout the 4-5 months of tourist season. Currently this slide show is conducted by few nature enthusiasts / interpreters / guides from the EDC members/local host community of Bhyundar / Pulna village trained by the office of the DFO \& Deputy Conservator of Forest, Nanda Devi National Park, Joshimath.

The Hemkund Sahib Geosystem`s information flux is considerable better developed, aligned to the latest technological advances. The smartphone geo-application created by Mebonix (Fig. 7) meet the basic needs of the pilgrims in search for general information about the geographical location coordinates, accessibility, accommodation, brief historical introduction, news and weather conditions (Mebonix, 2017).
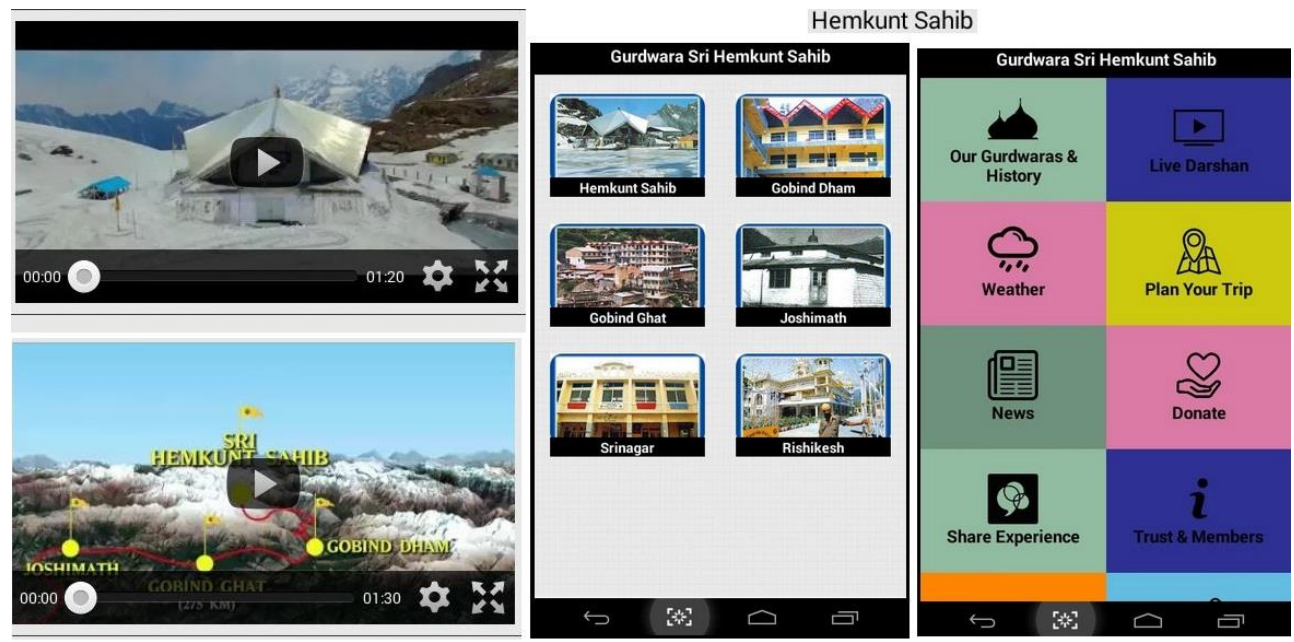

Fig. 7. The Sri Hemkund Sahib geo-application for Android (Mebonix, 2017).

Apart from the supervision of the smartphone applications development, the Sri Hemkund Sahib Management Trust is organizing and providing free accommodation (along with mattresses \& blankets), langar food, cloak room and toilets at Gurudwaras to visitors of all faiths and nationality. They make the arrangements for health care and free medical treatment at Gurudwara dispensaries, including ambulances at Govindghat, offer support in cases of any deaths along the trek journey and bears the cost voluntarily for the body transportation down to Govindghat and then to the place of choice of their relatives within India, irrespective of the deceased person belonging to any faith or nationality.

The Sri Hemkund Sahib Management Trust is also giving funds to EDC for the entire trek path maintenance/cleanliness in each tourist season and provides assistance through 
Gurudwara Sevadars (volunteers) for the trail repairs at higher altitudes after avalanches en route to Hemkund Sahib.

Valley of Flowers and Hemkund Sahib Geosystems coexist harmoniously in the Indian Himalayas because of the human factor, who responsibly intervened and established the institutional framework for the protection, conservation, planning and development of the geographical space. The main institutional stakeholders include the Eco-Development Committee (EDC), Gurudwara Sri Hemkund Sahib Management Trust (GSHSMT), Van Panchayat/Forest Council, Zila Panchayat (ZP) and the Department of Forests.

\section{Eco-Development Committee (EDC)}

In 2003 Eco-Development Committee (EDC) was set up under the provisions of State's Joint Forest Management Rules, and it took up the task of solid waste collection from June 2003 onwards. Their responsibilities are:

- To keep the trek trail clean and region free from polythene / plastics

- To provide employment opportunity to rural unemployed

- To conserve the environment of this valley region

- To provide facility of prepaid booking of mule/donkey

- To provide the yatrees /tourists all information and help

EDC collects the Eco-development fee from Mules and Commercial Establishments, utilizing funds from its revenue on training/capacity building of the local community members and local service providers with the assistance of Department of Forests.

The Van Panchayat Responsibilities mainly include Protection and Conservation of Forests under its Area as per Forest (Conservation) Act, 1980.The activities are:

-Patrolling of Forests/Land under its area and control over illegal tree felling pruning of tree branches, and fodder grazing

-Permit the individuals/tour operators to pitch tents on the Van Panchayat land at Kanjila for a nominal fee or lease for short-term for tent resorts every season.

Zilla Panchayat (ZP) has performed the following functions in the Valley of FlowersHemkund region:

- Maintains the ZP parking at Govindghat, fix the parking rates (large vehicle, small vehicle, two-wheelers) and collect the parking charges on contract

- Provides toilet facilities at Govindghat

- Provides land for mule sheds at Ghangharia and Govindghat.

- Fixation of rates for transportation services (mules/porters/palki) on the trek path

The Valley of Flowers-Hemkund region is a part of the Nanda Devi Biosphere Reserve (NDBR), and especially the Valleys of Flowers National Park being one of the two core zones (core zone-II) of the NDBR. The region is under active control of the Office of the District Forest Officer, Department of Forests, Joshimath. A Forest Range Officer is deployed in the region with facilities at Govindghat and Ghangharia. The management of the Valley of Flowers National Park has been based on the following objectives and considerations:

-Keeping control on the extent and wide spread growth of the fast growing and pioneering flowering herb - the Polygonum polystachyum.

- Development and upkeep of the trek route within the tourism zone of the park.

- Maintenance of the park and keeping it free from any kind of polluting material.

- Providing impetus to the tourism and providing local employment (through EDC, etc.).

- Strict control on illicit removal of herbs and on poaching. 


\section{CONCLUSIONS}

The Valley of Flowers Geosystem common attributes are harmoniously functioning in an interdependent relationship with all the environmental components and generate the natural dynamic of the perfectly equilibrated geosystem. But our exploratory research goal was not limited to the assessment of the common Himalayas`attributes such as those found in the Valley of Flowers Geosystem.

This research also investigated the special attributes presence in the natural Himalayas geosystems where the local communities were perfectly integrated. The findings confirmed that Hemkund Sahib Geosystem represents an excellent model of human-nature interaction. The results suggest that Hemkund Sahib unique functional attribute is based on the indigenous people cultural and historical heritage that helps them in the permanent adaptation to changes process. They naturally learn how to constantly adjust to new challenges. Interestingly, Hemkund Sahib- the famous Sikh Shrine is steadily emerging as a strong religious resort as well as a tourist destination despite the fact that its geographical location is not accessible by road. It involves an arduous trekking on a steep slope for the last six kilometers. Naturally, there is also dearth of way-side facilities. Despite this, the pilgrim arrivals recorded at 340578 in 2002 increased to 557129 in 2007 witnessing an overall increase by over $63.5 \%$ and per annum average growth of over $10.5 \%$ during the six years under reference. But similar trends followed in the year 2009, 2013, 2014 and 2015 due to climatic factors.

Statistics on non-pilgrim tourist destination, i.e., Valley of Flowers gives an idea on visitor trends to non-religious destinations located in the higher Himalayan part of India. Unfortunately, despite being world class destination for their extra-ordinary resource potential, it has largely failed to attract tourists anywhere close to the underlying potential. Valley of Flowers, the fabulously flower carpeted rock garden of Frank Smyth, which was declared as Biosphere Reserve in 1982, has been able to attract only 6944 tourists in 2007 as against 557129 pilgrims/tourists to nearby Hemkund Sahib. Such a poor share of the former appears to be all the more dismaying in view of the fact that till Ghangharia, there is common trek for the two destination and that Valley of Flowers is only about $4 \mathrm{~km}$ from there while Hemkund Sahib is located at $6.5 \mathrm{~km}$ from there and the trek is considerably arduous in case of the latter. True, that entry to the Valley is restricted on account of its highly fragile ecosystems, but still the number of visits is too less than the prevailing carrying capacity.

The research findings answer to all the access, security, hygiene, accommodation, transport and communication problems. Based on the results, we estimate an increasingly higher rate of development due to the technological advances that facilitate information sharing and the enhancement of the geographical place virtual illustration.

\section{R E F E R E N C E S}

Ernawati, N.M., Torpan, A. \& Voda, M. (2018) Geomedia role for mountain routes tourism development. Mesehe and Pisoiu Waterfall comparative study. Geographia Technica, 13 (1), 41 51.

Fonia, K.S. (1998) The Traveller's Guide To Uttarakhand, Garuda Books, Chamoli,Garhwal.

Google Earth. (2018). Google Earth. [Online]. Available from: www.google.com/earth/ [Accessed August 2018]. 
Gupta S. K. \& Vijay Prakash (2013), Tourism Development Pattern along Badri-Kedar Pilgrimage Circuit in Uttarakhand, India: A Destination Development Approach in the Himalayan Tsunami affected Region, Journal of Tourism: An International Journal, XIV (2), 67-76.

Gupta, S.K. (2002) Tourism \& Heritage Resources in Garhwal: An Approach to Planning and Management, Kavery Books, New Delhi.

Gupta, S.K. (2010) project report on The Changing Nature of Tourists Expectation and Development Forces Impacting the Future of Tourism in Badrinath and Kedarnath Tourism Circuit in Uttarakhand, funded by AICTE, NewDelhi.

Haidu, I. (2016) What Is Technical Geography. Geographia Technica, 11(1), 1-5. DOI: 10.21163/GT_2016.111.01

Kandari,O.P. \& Gusain, O.P. (2001) Garhwal Himmalaya: Nature, Culture \& Society, Trans Media, Srinagar.

Kaur, J. (1985) Himalayan Pilgrimage and the New Tourism, Himalayan Books, New Delhi.

Kuniyal, J.C., Jain, A.P. \& Shannigrahi, A.S. (1998) Public involvement in solid waste management in Himalayan trails in and around the Valley of Flowers, India. Resources, Conservation and Recycling, 24, 299-322.

Mebonix. (2017) Sri Hemkund Sahib (Official) APK. [Online]. Available from: https://apkpure.com/sri-Hemkund-sahib-official/com.tds.Hemkundsahib [Accessed June 2018].

Pic2Map. (2018) EXIF data embedded in the image to find the GPS coordinates. [Online]. Available from: https://www.pic2map.com/ [Accessed September 2018].

Smythe, F.S. (1938) The Valley of Flowers (reprint), Natraj Pub, Rajpur Road, Dehradun.

Voda, M., Moldovan, L., Torpan, A., \& Henning, A. (2014) Using GIS for mountain wild routes assessment in order to qualify them for tourism valorisation. Geographia Technica, 9 (1),101108.

Voda, M., Torpan, A. \& Moldovan, L. (2017) Wild Carpathia Future Development: From Illegal Deforestation to ORV Sustainable Recreation. Sustainability, 9(2254), 1-11. 